\title{
S-Glycosides: Synthesis of S-linked Arabinoxylan Oligosaccharides
}

\author{
Romanó, Cecilia; Jiang, Hao; Boos, Irene; Clausen, Mads Hartvig
}

Published in:

Organic \& Biomolecular Chemistry

Link to article, DOI:

10.1039/D0OB00470G

Publication date:

2020

Document Version

Peer reviewed version

Link back to DTU Orbit

Citation (APA):

Romanó, C., Jiang, H., Boos, I., \& Clausen, M. H. (2020). S-Glycosides: Synthesis of S-linked Arabinoxylan Oligosaccharides. Organic \& Biomolecular Chemistry, 18, 2696-2701. https://doi.org/10.1039/D0OB00470G

\section{General rights}

Copyright and moral rights for the publications made accessible in the public portal are retained by the authors and/or other copyright owners and it is a condition of accessing publications that users recognise and abide by the legal requirements associated with these rights.

- Users may download and print one copy of any publication from the public portal for the purpose of private study or research.

- You may not further distribute the material or use it for any profit-making activity or commercial gain

- You may freely distribute the URL identifying the publication in the public portal

If you believe that this document breaches copyright please contact us providing details, and we will remove access to the work immediately and investigate your claim 


\section{Organic and Biomolecular Chemistry}

\section{ARTICLE}

\section{S-Glycosides: Synthesis of $S$-linked Arabinoxylan Oligosaccharides}

Received 00th January 20xx, Accepted 00th January 20xx

DOI: $10.1039 / x 0 \times x 00000 x$

\author{
Cecilia Romanò, ${ }^{a}$ Hao Jiang, ${ }^{a}$ Irene Boos ${ }^{a}$ and Mads H. Clausen ${ }^{a}$
}

\begin{abstract}
S-Glycosides are important tools for the elucidation of specific protein-carbohydrate interactions and can significantly aid structural and functional studies of carbohydrate-active enzymes, as they are often inert or act as enzyme inhibitors. In this context, this work focuses on the introduction of an S-linkage into arabinoxylan oligosaccharides (AXs) in order to obtain a small collection of synthetic tools for the study of AXs degrading enzymes. The key step for the introduction of the $S$ glycosidic linkage involved anomeric thiol S-alkylation of an orthogonally protected L-arabinopyranoside triflate. The resulting $S$-linked disaccharide was subsequently employed in a series of glycosylation reactions to obtain a selectively protected tetrasaccharide. This could be further elaborated through chemoselective deprotection and glycosylation reactions to introduce branching L-arabinofuranosides.
\end{abstract}

\section{Introduction}

In an effort to shift our economy towards more sustainable resources, research into the bioconversion of lignocellulosic biomass to produce second generation bioethanol and value added chemicals has flourished during the last two decades. ${ }^{1-4}$ This feedstock, an intricate structure of cellulose, hemicellulose, and lignin, is cheap, abundant, and sustainable. In fact, it represents the non-edible component of plant biomass and it is generally obtained from agricultural waste, pulp and paper industry waste, and deciduous woods, meaning that its utilization does not interfere with the cultivation of food supplies. $^{5-7}$ Hemicellulose constitutes around $20-35 \%$ of lignocellulosic biomass and is mainly composed of four structurally diverse polysaccharides: xylans, mannans, xyloglucans, and glucans, including mixed linkage glucans. ${ }^{8}$ Hemicellulosic arabinoxylans $(A X)$ are an important xylan subclass, where the $\beta$ - $(1 \rightarrow 4)$-linked $D$-xylopyranoside backbone is substituted by $\alpha-(1 \rightarrow 2)$ and/or $\alpha-(1 \rightarrow 3)$ L-arabinofuranosyl residues. $A X$ is mostly found as the main polysaccharide in a variety of tissues of commercial cereals, such as wheat, rye, barley, oat, rice, and corn - and AXs from cereal-processing byproducts represent an attractive and underutilized feedstock resource. 8,9

The process from raw biomass to value-added products requires pre-treatment of the material to break the lignin seal and allow for further degradation to its monosaccharide components. ${ }^{4,5,7}$ To this end, enzymatic bioconversion has been investigated as a valuable alternative to conventional hydrothermal and chemical processes. $3,8,10$ The biodegradation of hemicellulose, and in particular of AXs into their sugar

a. Center for Nanomedicine \& Theranostics, Department of Chemistry, Technical University of Denmark, Kemitorvet 207, DK-2800 Kgs. Lyngby, Denmark. E-mail: mhc@kemi.dtu.dk

Electronic Supplementary Information (ESI) available: experimental procedures; NMR spectra. See DOI: 10.1039/x0xx00000x constituents, xylan and arabinose, is of great interest for the production of advanced biofuels. ${ }^{11}$ Moreover, the partial degradation of AXs to arabinoxylooligosaccharides (AXOs) opens the possibility for their application as prebiotics. ${ }^{12,13}$ The main enzymes required for the degradation of AXs are endo-1,4$\beta$-D-xylanases (EC 3.2.1.8), 1,4- $\beta$-D-xylosidase (EC 3.2.1.37), and $\alpha$-L-arabinofuranosidases (AFs) (EC 3.2.1.55). ${ }^{3,7,14}$ In order to exploit these enzymes efficiently in the bioconversion of hemicellulose feedstocks, there is a need for systematic investigations of their substrate specificities.
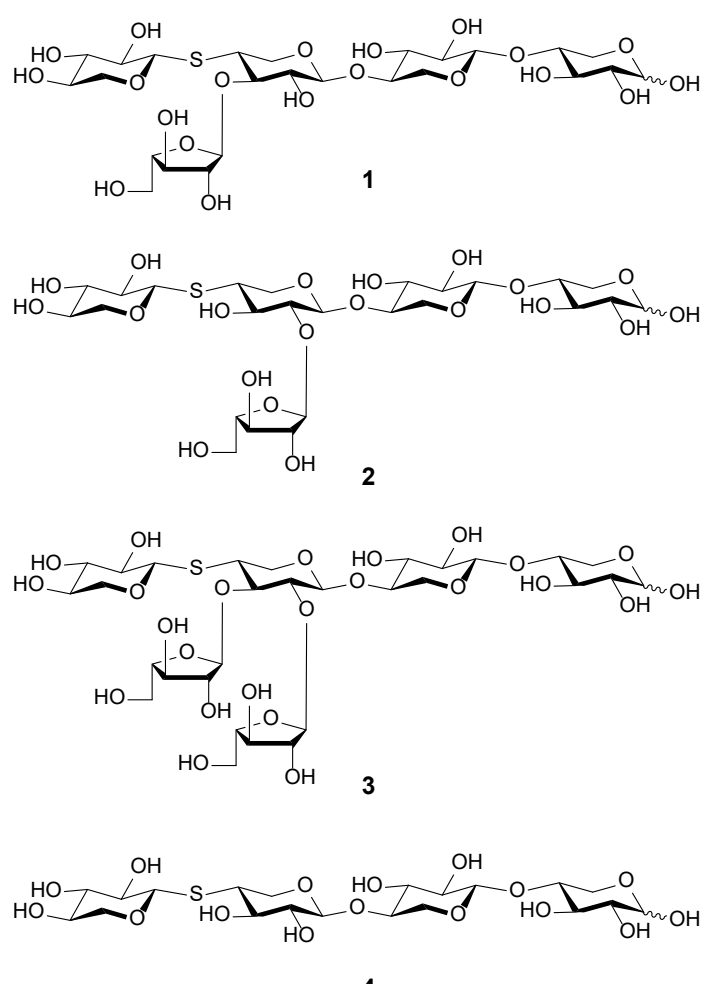

Chart 1: Targeted AXs derivatives 1-3 and tetraxylan 4 


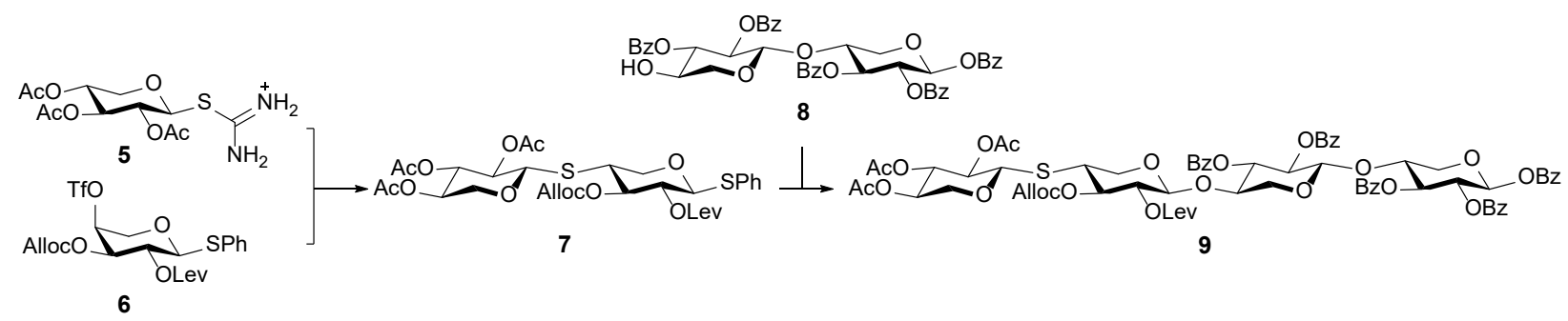

Figure 1: Synthetic approach for targets 1-3

While collections of synthetically defined xylo- and arabinoxylooligosaccharides obtained through chemical synthesis ${ }^{15-20}$ or chemoenzymatic methodologies ${ }^{21}$ can greatly contribute to define specificities and preferences of some $A X$ degrading enzymes, unique structure-activity information can be obtained by utilizing resistant substrates such as thiooligosaccharides. These unnatural compounds, where at least one glycosidic oxygen atom is replaced by a sulphur atom, are mimics acting as competitive inhibitors of many glycosyl hydrolases, thus representing excellent tools for biochemical and structural investigations of carbohydrate processing enzymes. ${ }^{22,23}$

Synthetically, a thio-linkage can be introduced in one of two ways: 1) by a glycosylation reaction between a suitable glycosyl donor and a thiol acceptor (via a classical acid-catalysed $S$ glycosylation ${ }^{24-26}$ or via a base-promoted glycosylation consisting of a $\mathrm{S}_{\mathrm{N}} 2$ displacement of a glycosyl halide by a thiolate $\left.{ }^{27-30}\right)$; or 2) through anomeric thiol $S$-alkylation, consisting in the reaction of a saccharide electrophile with a nucleophilic anomeric thiol moiety. ${ }^{31-35}$ Both strategies, which have been extensively reviewed, ${ }^{36}$ have been exploited for the synthesis of several S-linked oligosaccharides. Recently, we have presented our synthetic approaches towards the synthesis of an S-linked tetraxylan. ${ }^{37}$ Several strategies for the formation of the thio-linkage were explored and methods involving 1thioglycosides were found to be preferable due to a reduction of by-products. As a natural progression of this previous research, we have been interested in the preparation of S-linked arabinoxylan derivatives 1-3, together with the optimization of the synthesis of linear S-linked tetraxylan 4 (Chart 1). These targets are ideal substrates for the study of AXs degrading enzymes: their backbone, with four D-xylopyranose residues, has a suitable length for recognition by both endo-1,4- $\beta$-Dxylanases and 1,4- $\beta$-D-xylosidases. ${ }^{14,38}$ Moreover, the presence of different branching patterns of L-arabinofuranosyl residues gives the opportunity to pinpoint both $\alpha$-L-arabinofuranosidase activity and the selectivity of those enzymes that are believed to have a mixed xylanases/arabinofuranosidase activity. ${ }^{14,39}$

\section{Results and discussion}

\section{Synthesis of branched S-linked arabinoxylans 1-3}

To access the desired branched target structures 1-3, the key $S$ linked tetrasaccharide 9 was designed (Figure 1). The structure is 2"-O-levulinoyl (Lev) and 3"-O-allyloxycarbonyl (Alloc) substituted, thus allowing the regioselective unmasking of either 2"-OH or 3"-OH for further glycosylation with an Larabinofuranoside donor. Moreover, acetyl and benzoyl ester groups are employed as global protecting groups to ease the final deprotection of the assembled structures in the presence of the $S$-linkage. For the synthesis of key intermediate $\mathbf{9}$, a [2+2] building block strategy with the orthogonally protected $S$-linked disaccharide donor $\mathbf{7}$ and 4'-OH acceptor 8 was employed. For the synthesis of thio-linked disaccharide 7 , an anomeric thiol group $S$-alkylation methodology was selected, with isothiourea xyloside 5 and the 4-O-trifluoromethanesulphonyl Larabinopyranoside 6 as the coupling pair (Figure 1). This choice of strategy is justified by both the ease of access of building blocks $\mathbf{5}$ and $\mathbf{6}$ as well as the greater robustness of isothioureabased couplings compared to those involving the use of free thiol substrates.

While isothiouronium salt $\mathbf{5}$ could be easily accessed in one step from 2,3,4-tri-O-acetyl- $\beta$-D-xylopyranosyl bromide $10^{40}$ in $98 \%$ yield, the preparation of building block 6 required more protecting group manipulations (Scheme 1). 3,4-OIsopropylidene L-arabinopyranoside $\mathbf{1 1}^{41}$ was treated with levulinic acid, DCC, and DMAP in anhydrous $\mathrm{CH}_{2} \mathrm{Cl}_{2}$ to afford derivative 12 in $84 \%$ yield. After removal of the 3,4-O-

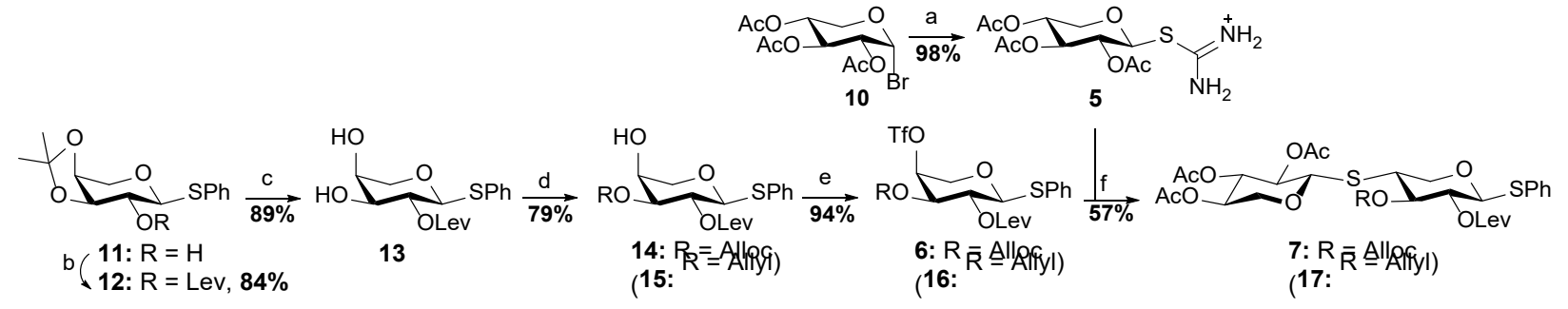

Scheme 1: Reagents and conditions: (a) thiourea, $\mathrm{CH}_{3} \mathrm{CN}$, reflux, $10 \mathrm{~min}$; (b) levulinic acid, DCC, DMAP, $\mathrm{CH}_{2} \mathrm{Cl}_{2}, \mathrm{RT}, 6 \mathrm{~h}$; (c) $80 \%$ aq. AcOH, $60{ }^{\circ} \mathrm{C}, 3 \mathrm{~h}$; (d) allyl chloroformate, $\mathrm{CH}_{2} \mathrm{Cl}_{2}$ /pyridine, $-30{ }^{\circ} \mathrm{C}, 2 \mathrm{~h}$; (e) $\mathrm{Tf}_{2} \mathrm{O}, \mathrm{CH}_{2} \mathrm{Cl}_{2} /$ pyridine, $0{ }^{\circ} \mathrm{C}, 15 \mathrm{~min}$; (f) $\mathrm{Et}{ }_{3} \mathrm{~N}, \mathrm{DMF} / \mathrm{CH}_{3} \mathrm{CN}, \mathrm{RT}, 2 \mathrm{~h}$. 


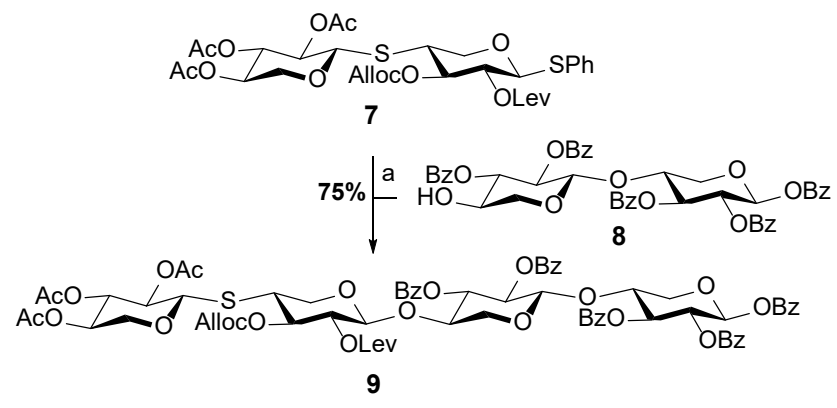

Scheme 2: (a) NIS/AgOTf, $\mathrm{CH}_{2} \mathrm{Cl}_{2}, 4 \AA \mathrm{MS} ;-10^{\circ} \mathrm{C} \rightarrow 0{ }^{\circ} \mathrm{C}, 1 \mathrm{~h}$.

isopropylidene group under acidic conditions $(\rightarrow \mathbf{1 3}, 89 \%)$, position 3 of the diol was regioselectively protected with an allyloxycarbonyl group. The reaction, performed with allyl chloroformate at $-30{ }^{\circ} \mathrm{C}$ afforded 14 in $79 \%$ yield. Careful control of the temperature proved essential for the preparation of the desired compound and only trace amounts of double protected 3,4-O-allyloxycarbonyl were formed during the reaction. Finally, compound $\mathbf{1 4}$ was reacted with trifluoromethanesulphonic anhydride in pyridine $/ \mathrm{CH}_{2} \mathrm{Cl}_{2}$ to afford building block 6 in $94 \%$ yield. The coupling reaction of building blocks 5 and 6 proceeded in a 33\% yield in anhydrous $\mathrm{CH}_{3} \mathrm{CN}$. A more satisfactory yield of $57 \%$ was obtained when the solvent was substituted with a 1:1 mixture of anhydrous $\mathrm{CH}_{3} \mathrm{CN}$ and DMF and only 1.2 equivalents of 6 were employed. While no significant by-products were observed and unreacted triflate 6 could be recovered from the reaction mixture, it was not possible to isolate unreacted isothiouronium salt (the limiting reagent). Albeit not particularly high yielding, this first report on the formation of the key $S$-glycosidic linkage with an orthogonally protected building block, as opposed to the use of per-acetylated/per-benzoylated substrates, ${ }^{31}$ allows explorations into the synthesis of more complex S-glycosides. In order to compare reactivity to the use of ether-type protecting groups in position 3 , allyl protected derivative $\mathbf{1 5}$ was also synthesized on a test scale and converted to its triflate derivative 16. Coupling of 16 with isothiouronium salt 5 afforded the desired product 17 in $41 \%$ yield when reacted under the same conditions as $\mathbf{7}$. While proving that the methodology can be extended to a larger set of protecting groups, it is important to note that the later deprotection of ether-type protecting groups, such as benzyl and allyl, could prove difficult due to the presence of the thio-linkage.
Key disaccharide $\mathbf{7}$ was then reacted with acceptor $\mathbf{8}$, in the presence of several promoting systems (Scheme 2, Table 1). A test reaction with $\mathrm{NIS} / \mathrm{TfOH}$ at low temperature $\left(-50{ }^{\circ} \mathrm{C}\right)$ afforded by-product 18, evidence of post-glycosylation hydrolysis of the thio-linkage, followed by dimerization to form the disulphide (entry 1). DMTST promoted glycosylation proved to be incompatible with the Alloc functionality (entry 2), while MeOTf did not afford any conversion over 24 hours (entry 3 ). On the other hand, and to our delight, glycosylation with NIS/AgOTf at $0{ }^{\circ} \mathrm{C}$ afforded the desired product 9 in a $77 \%$ yield (entry 4). Glycosylation at lower temperatures $\left(-40{ }^{\circ} \mathrm{C}\right.$ to -10 ${ }^{\circ} \mathrm{C}$ ) did not afford activation of the phenyl thioglycoside. Interestingly, the reaction proceeded smoothly and without affecting the $S$-interglycosidic linkage, despite the use of thiophilic NIS. With tetrasaccharide 9 in hand, orthogonal deprotections to afford acceptors $\mathbf{1 9}$ and $\mathbf{2 0}$ were performed (Scheme 3). Alloc removal proceeded in a $65 \%$ yield in the presence of $\mathrm{Pd}\left(\mathrm{PPh}_{3}\right)_{4}$ to give 19. Similarly, Lev removal with hydrazine acetate afforded $\mathbf{2 0}$ in $\mathbf{7 9 \%}$ yield. Gratifyingly, both compounds reacted quickly and in high yields in TMSOTfpromoted glycosylation reactions with the 2,3,5-tri-O-benzoyl$\alpha$-L-arabinofuranosyl trichloroacetimidate donor $\mathbf{2 1}^{42}(\rightarrow \mathbf{2 2}$, quant.; $\rightarrow \mathbf{2 3}, 93 \%)$. The newly formed pentasaccharides $\mathbf{2 2}$ and 23 were then deprotected under standard conditions to afford desired targets $\mathbf{1}$ and $\mathbf{2}$ in $80 \%$ and $45 \%$ yield, respectively. In a similar manner, intermediate 9 was subjected to Alloc deprotection, followed by Lev removal to obtain 2 ", 3 "'-diol acceptor $\mathbf{2 4}$ in $\mathbf{7 2 \%}$ yield over two steps. Compound $\mathbf{2 4}$ was subsequently reacted with donor $\mathbf{2 1}$ (2.5 equiv.) in the presence of TMSOTf to give hexasaccharide $\mathbf{2 5}$ in $\mathbf{9 7 \%}$ yield. A Zemplén reaction finally afforded desired target 3 in $82 \%$ yield.

\section{Synthesis of $S$-linked tetraxylan 4}

Our previous approach towards the synthesis of $\mathbf{4}$ involved the preparation of a trifluoroacetimidate donor and its reaction with a thio-acceptor. In this work, a simpler route, inspired by the one presented in the previous section, was devised. The $S$ linkage was synthesised from xylothiouronium salt $\mathbf{5}$ and Larabinopyranoside triflate derivative $\mathbf{2 8}$, which was synthesized in 4 steps from 10: acetylation under standard conditions and cleavage of the 3,4-O-isopropylidene group $(\rightarrow \mathbf{2 6}, 91 \%$ over 2 steps) was followed by selective benzoylation to afford $3-\mathrm{OBz}$ derivative $\mathbf{2 7}$ in $63 \%$ yield.

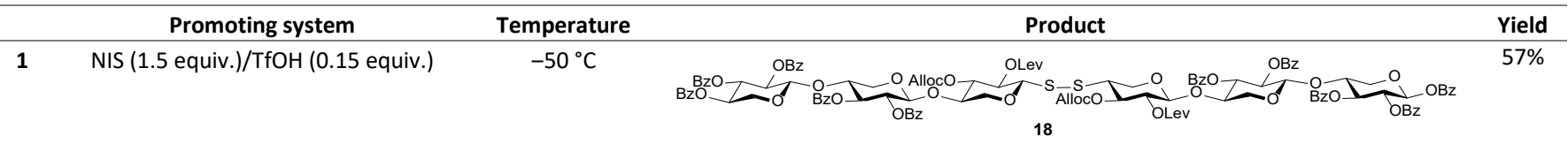

\begin{tabular}{lcccc}
\hline $\mathbf{2}$ & $\mathrm{DMTST}(3$ equiv.) & $0{ }^{\circ} \mathrm{C} \rightarrow \mathrm{RT}$ & \multicolumn{2}{c}{ Decomposition - Alloc incompatible with DMTST } \\
\hline $\mathbf{3}$ & MeOTf (5 equiv.) & $\mathrm{RT}$ & No reaction & - \\
\hline $\mathbf{4}$ & NIS (1.5 equiv.)/AgOTf $(0.25$ equiv.) & $-10{ }^{\circ} \mathrm{C} \rightarrow 0{ }^{\circ} \mathrm{C}$ &
\end{tabular}

Table 1: Test glycosylations with donor $\mathbf{7}$ and acceptor $\mathbf{8}$ 


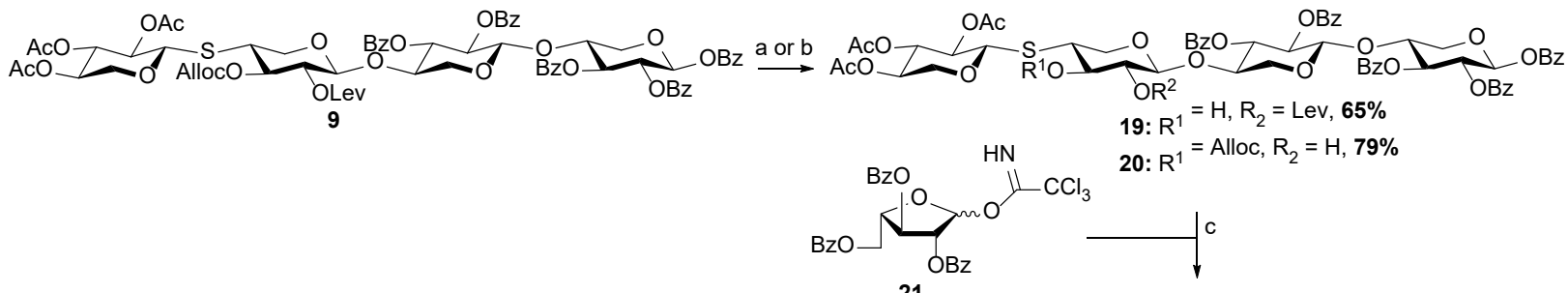

21

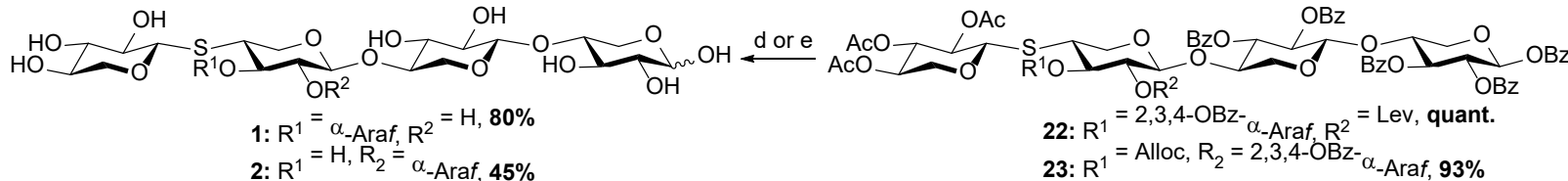

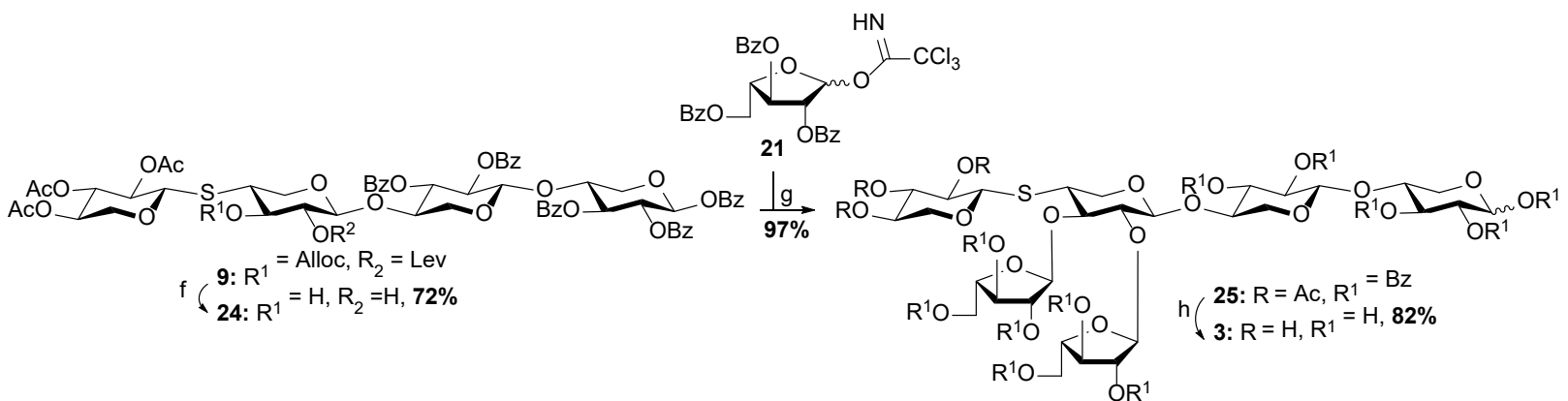

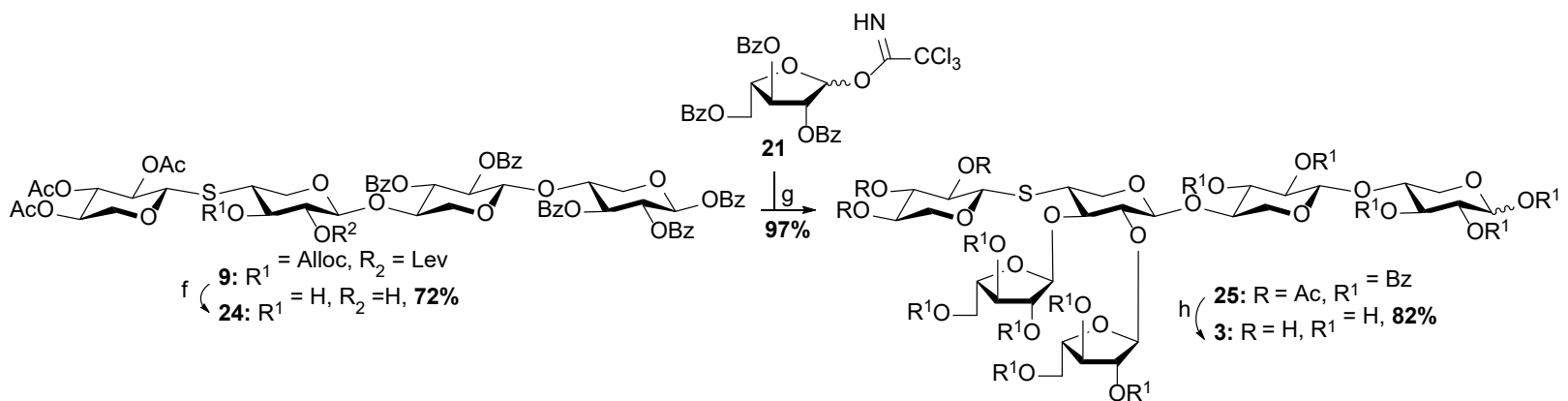
23: $\mathrm{R}^{1}=$ Alloc, $\mathrm{R}_{2}=2,3,4-\mathrm{OBz}-{ }_{-}$-Araf, $93 \%$

Scheme 2: Reagents and conditions: for 19: (a) $\mathrm{Pd}\left(\mathrm{PPh}_{3}\right)_{4}, \mathrm{AcOH}, \mathrm{RT}, 5 \mathrm{~h}$; for 20: (b) $\mathrm{H}_{2} \mathrm{NNH}_{2} \cdot \mathrm{HOAc}, \mathrm{AcOH} / \mathrm{pyridine}, \mathrm{RT}, 10 \mathrm{~min}$; (c) TMSOTf, $\mathrm{CH} \mathrm{Cl}_{2}, 4 \AA$ A $,-40{ }^{\circ} \mathrm{C}, 15 \mathrm{~min}$; for 1: (d) (i) $\mathrm{H}_{2} \mathrm{NNH}_{2} \cdot \mathrm{HOAc}, \mathrm{MeOH} / \mathrm{CH}_{2} \mathrm{Cl}_{2}, \mathrm{RT}, 3 \mathrm{~h}$, (ii) $\mathrm{MeONa}, \mathrm{CH}_{2} \mathrm{Cl}_{2} / \mathrm{MeOH}, \mathrm{RT}, 16 \mathrm{~h}$; for 2: (e) (i) $\mathrm{Pd}(\mathrm{PPh} 3)_{4}, \mathrm{THF} / \mathrm{H}_{2} \mathrm{O}, \mathrm{RT}$, $3 \mathrm{~h}$, (ii) $\mathrm{MeONa}$, $\mathrm{CH}{ }_{2} \mathrm{Cl} 2 / \mathrm{MeOH}, \mathrm{RT}, 16 \mathrm{~h}$; (f) (i) $\mathrm{Pd}\left(\mathrm{PPh}_{3}\right)_{4}, \mathrm{THF} / \mathrm{H}_{2} \mathrm{O}, \mathrm{RT}$, 3h, (ii) $\mathrm{H}_{2} \mathrm{NNH}_{2} \cdot \mathrm{HOAc}$, AcOH/pyridine, $\mathrm{RT}, 10 \mathrm{~min}$; (g) TMSOTf, $\mathrm{CH}_{2} \mathrm{Cl}_{2}, 4 \AA$, $,-60{ }^{\circ} \mathrm{C}, 20 \mathrm{~min}$; (h) $\mathrm{MeONa}, \mathrm{CH} \mathrm{Cl}_{2} / \mathrm{MeOH}^{\mathrm{RT}}, 16 \mathrm{~h}$.

Interestingly, attempted selective acetylation of the 3,4-diol under similar conditions ( 1.1 equiv. $\mathrm{AcCl}$, pyridine, $-30^{\circ} \mathrm{C}$ ) gave an inseparable 1:1 mixture of 3-OAc and 4-OAc products, possibly because of a higher rate of 3-O-acetyl ester migration from position 3 to 4 , compared to the 3-O-benzoyl ester. Reaction of $\mathbf{2 7}$ with trifluoromethanesulphonic anhydride and pyridine gave compound $\mathbf{2 8}$ in $93 \%$. The subsequent coupling reaction with isothiouronium salt 5 afforded S-disaccharide 29

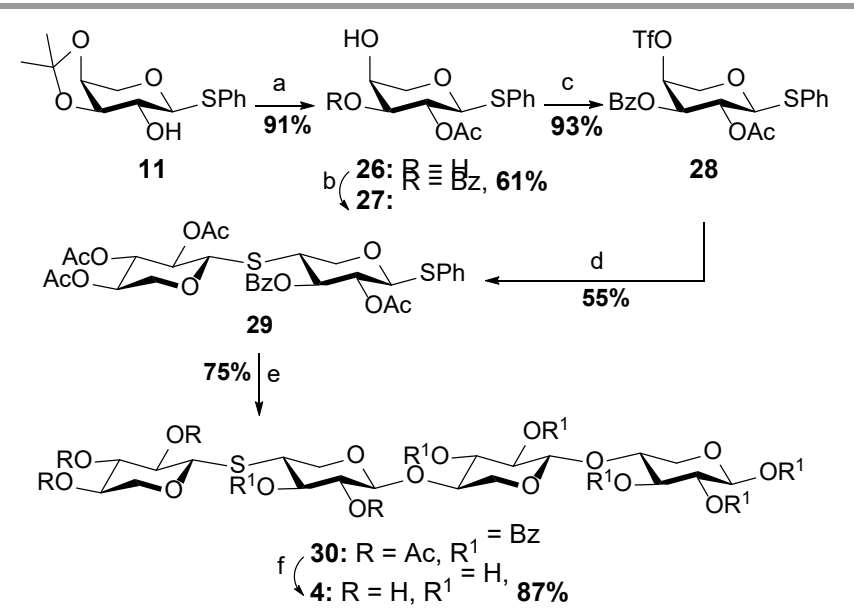

Scheme 3: Reagents and conditions: (a) (i) $\mathrm{Ac}_{2} \mathrm{O}$, pyridine, $\mathrm{RT}, 16 \mathrm{~h}$, (ii) aq. $80 \%$ $\mathrm{AcOH}, 60{ }^{\circ} \mathrm{C}, 4 \mathrm{~h}$; (b) $\mathrm{BzCl}$, pyridine, $-35^{\circ} \mathrm{C}, 1 \mathrm{~h}$; (c) $\mathrm{Tf}_{2} \mathrm{O}, \mathrm{CH}_{2} \mathrm{Cl}_{2} /$ pyridine, $0{ }^{\circ} \mathrm{C}, 45$ $\min$; (d) 5, $\mathrm{Et}_{3} \mathrm{~N}, \mathrm{CH}_{3} \mathrm{CN}, \mathrm{RT}, 16 \mathrm{~h}$; (e) 8, NIS/AgOTf, $\mathrm{CH}_{2} \mathrm{Cl}_{2}, 4 \AA \mathrm{MS} ;-15^{\circ} \mathrm{C} \rightarrow 0{ }^{\circ} \mathrm{C}$, 30 min; (f) $\mathrm{MeONa}, \mathrm{CH}_{2} \mathrm{Cl}_{2} / \mathrm{MeOH}, \mathrm{RT}, 16 \mathrm{~h}$. in $55 \%$ yield. Although similar in yield to the reaction described in our previous work with a trifluoroacetimidate donor and a thio-acceptor, ${ }^{37}$ the conversion, although incomplete, is cleaner and affords the possibility of isolating unreacted $\mathbf{2 8}$ for recycling as little elimination of the triflate is observed. Glycosylation of newly synthesized $\mathbf{2 9}$ with acceptor $\mathbf{8}$ afforded tetrasaccharide 30 in $75 \%$ yield. Again, the promoting system NIS/AgOTf uniquely activated the thioglycoside at the reducing end of $\mathbf{2 9}$, without affecting the $S$-interglycosidic linkage. Final deprotection under Zemplén conditions afforded tetrasaccharide 4 in $87 \%$ yield.

\section{Conclusions}

A synthetic route towards the preparation of four substrates for the study of $A X$ degrading enzymes has been developed. The key unnatural $S$-linkage was introduced by coupling with an orthogonally protected L-arabinopyranoside, and proved to be compatible with deprotection reactions under mild conditions in the presence of the interglycosidic thio-linkage. Interestingly, the resulting $S$-linked disaccharide could be employed directly as a thioglycoside donor in a [2+2] glycosylation for the synthesis of the linear tetraxylan when AgOTf/NIS was employed as promoting system. While some examples of hydrolysis of phenyl thioglycosides with inner S-glycosidic linkages can be found in the literature, ${ }^{37,43}$ to the best of our knowledge this is the first report on the activation of a phenyl thioglycoside in the presence of an interglycosidic $S$-linkage for 
a subsequent glycosylation. The reactivity of the two sulphur atoms in donors $\mathbf{7}$ and $\mathbf{2 9}$ is likely to be influenced similarly by the protecting groups at $\mathrm{C}-2 / \mathrm{C}-2^{\prime}$ as well as elsewhere, since they are all disarming. ${ }^{44,45}$ Instead, the chemoselectivity observed may stem from variation in nucleofugicity ${ }^{46}$ or steric deactivation. ${ }^{46,47}$ Moreover, glycosylation reactions with the Larabinofuranosyl imidate donor in the presence of TMSOTf proved to not affect the $S$-interglycosidic linkage.

\section{Conflicts of interest}

There are no conflicts to declare.

\section{Acknowledgements}

We are grateful to the Villum Foundation (grant no. 9283), the Novo Nordisk Foundation (grant no. NNF180C0053048), and the Danish Council for Independent Research (grant no. 904100080B) for supporting our research. C. R. acknowledges financial support from the European Commission's ARGONAUT project (grant agreement no. 841278). The $800 \mathrm{MHz} N M R$ data were recorded at the NMR Center at DTU supported by the Villum Foundation.

\section{References}

D. Dodd and I. K. O. Cann, GCB Bioenergy, 2009, 1, 2-17. V. Menon and M. Rao, Prog. Energy Combust. Sci., 2012, 38, 522-550. F. Peng, P. Peng, F. Xu and R. C. Sun, Biotechnol. Adv., 2012, 30, 879-903. F. H. Isikgor and C. R. Becer, Polym. Chem., 2015, 6, 4497. S. Haghighi Mood, A. Hossein Golfeshan, M. Tabatabaei, G. Salehi Jouzani, G. H. Najafi, M. Gholami and M. Ardjmand, Renew. Sustain. Energy Rev., 2013, 27, 77-93. D. Loqué, H. V. Scheller and M. Pauly, Curr. Opin. Plant Biol., 2015, 25, 151-161.

7 D. S. Naidu, S. P. Hlangothi and M. J. John, Carbohydr. Polym., 2018, 179, 28-41. B. C. Saha, J. Ind. Microbiol. Biotechnol., 2003, 30, 279-291. A. Ebringerová and Z. Hromádková, Biotechnol. Genet. Eng. Rev., 1999, 16, 325-346.

P. Biely, S. Singh and V. Puchart, Biotechnol. Adv., 2016, 34 1260-1274.

Q. Li, J. Song, S. Peng, J. P. Wang, G.-Z. Qu, R. R. Sederoff and V. L. Chiang, Plant Biotechnol. J., 2014, 12, 1174-1192.

12 H. Pastell, P. Westermann, A. S. Meyer, T. Päivi and M. Tenkanen, J. Agric. Food Chem., 2009, 57, 8598-8606.

13 E. Nordberg Karlsson, E. Schmitz, J. A. Linares-Pastén and P. Adlercreutz, Appl. Microbiol. Biotechnol., 2018, 102, 9081-

9088.

14

15

16

17

18

20

21
S. Lagaert, A. Pollet, C. M. Courtin and G. Volckaert, Biotechnol. Adv., 2014, 32, 316-332.

K. Takeo, Y. Ohguchi, R. Hasegawa and S. Kitamura, Carbohydr. Res., 1995, 278, 301-313.

L. Chen and F. Kong, Carbohydr. Res., 2002, 337, 23352341.

D. Schmidt, F. Schuhmacher, A. Geissner, P. H. Seeberger and F. Pfrengle, Chem. - A Eur. J., 2015, 21, 5709-5713.

D. Senf, C. Ruprecht, G. H. M. de Kruijff, S. O. Simonetti, F. Schuhmacher, P. H. Seeberger and F. Pfrengle, Chem. - A Eur. J., 2017, 23, 3197-3205.

M. J. Pedersen, R. Madsen and M. H. Clausen, Chem. Commun., 2018, 54, 952-955.

E. N. Underlin, M. Böhm and R. Madsen, J. Org. Chem., 2019, 84, 16036-16054.

D. Senf, C. Ruprecht, S. Kishani, A. Matic, G. Toriz, P. Gatenholm, L. Wågberg and F. Pfrengle, Angew. Chem. Int. Ed. Engl., 2018, 130, 12163-12168.

H. Driguez, ChemBioChem, 2001, 2, 311-318.

Y. W. Kim, A. L. Lovering, H. Chen, T. Kantner, L. P. McIntosh, N. C. J. Strynadka and S. G. Withers, J. Am. Chem. Soc., 2006, 128, 2202-2203.

D. Crich and H. Li, J. Org. Chem., 2000, 65, 801-805. J. S. Andrews, B. D. Johnston and B. M. Pinto, Carbohydr. Res., 1998, 310, 27-33.

B. D. Johnston and B. M. Pinto, Carbohydr. Res., 1998, 310, 17-25.

M. Blanc-Muesser, J. Defaye and H. Driguez, Carbohydr. Res., 1978, 67, 305-328.

L. A. Reed and L. Goodman, Carbohydr. Res., 1981, 94, 91100.

V. Moreau, J. C. Norrild and H. Driguez, Carbohydr. Res., 1997, 300, 271-277.

H. Cao and B. Yu, Tetrahedron Lett., 2005, 46, 4337-4340.

F. M. Ibatullin, K. A. Shabalin, J. V. Jänis and S. I. Selivanov, Tetrahedron Lett., 2001, 42, 4565-4567.

F. M. Ibatullin, S. I. Selivanov and A. G. Shavva, Synthesis (Stuttg)., 2001, 3, 419-422.

H. N. Yu, C. C. Ling and D. R. Bundle, J. Chem. Soc. Perkin 1, 2001, 832-837.

C. S. Rye and S. G. Withers, Carbohydr. Res., 2004, 339, 699-703.

G. Hummel and O. Hindsgaul, Angew. Chemie - Int. Ed., 1999, 38, 1782-1784. 
K. Pachamuthu and R. R. Schmidt, Chem. Rev., 2006, 106, 160-187.

37 B. Bonora, I. Boos and M. H. Clausen, Carbohydr. Res., 2017, 443-444, 53-57.

P. Biely, Z. Krátký and M. Vrsanská, Eur. J. Biochem., 1981, 119, 559-64.

39 K. Wagschal, C. Heng, C. C. Lee and D. W. S. Wong, Appl. Microbiol. Biotechnol., 2009, 81, 855-863.

40 J. Camponovo, C. Hadad, J. Ruiz, E. Cloutet, S. Gatard, J. Muzart, S. Bouquillon and D. Astruc, J. Org. Chem., 2009, 74, 5071-5074.

41 W. Yu and Z. Jin, J. Am. Chem. Soc., 2001, 123, 3369-3370.

42 Y. Du, Q. Pan and F. Kong, Carbohydr. Res., 2000, 329, 1724.

43 H. Tanaka, Y. Yoshimura, N. J. Dovichi, M. M. Palcic and O. Hindsgaul, Tetrahedron Lett., 2012, 53, 1812-1815.

D. R. Mootoo, P. Konradsson, U. Udodong and B. FraserReid, J. Am. Chem. Soc., 1988, 110, 5583-5584.

45

Z. Y. Zhang, I. R. R. Ollmann, X.-S. S. Ye, R. Wischnat, T. Baasov and C.-H. H. Wong, J. Am. Chem. Soc., 1999, 121, 734-753.

P. J. Garegg, Adv. Carbohydr. Chem. Biochem., 1997, 52, 179-205. 1997, 62, 8145-8154. 